\title{
Eponyms in Dance Terminology as an Object of Translation
}

\author{
Judyta Mężyk \\ University of Silesia in Katowice, Poland \\ University Paris-Est Créteil Val de Marne, France \\ judyta.mezyk@us.edu.pl
}

\begin{abstract}
This paper raises both the issue of eponyms emerging in dance terminology and problems concerning their translation. In Section 1, a short introduction to the topic is presented. Section 2 covers theoretical background crucial to understand the topic, defining the notion of eponym vital to the paper as well as that of sociolect of the dance community. Moving on to the methodology of this research, Section 3 contains the corpus of 56 Polish eponyms in dance terminology, gathered mostly from books such as Kopalinski's "Stownik eponimów, czyli wyrazów odimiennych" (1996), his "Słownik wyrazów obcych i zwrotów obcojęzycznych" (2003), Chodkowski's "Encyklopedia muzyki” (1995), Dąbrowska's "W kręgu polskich tańców ludowych" (1979) and during various lectures conducted by dance teachers, along with their English translations. Then, a quantitative and qualitative analysis of the corpus is discussed. Finally, in Section 4, conclusion of the research is presented to show the complexity of the issue of eponyms and problems that may occur in their translation.
\end{abstract}

Keywords: eponym, translation, dance terminology, sociolect, social dialect

Streszczenie

Przekład eponimów w terminologii tanecznej

Niniejszy artykut porusza temat eponimów $w$ terminologii tanecznej oraz omawia możliwe problemy $w$ ich tlumaczeniu. W Części 1 przedstawione jest krótkie wprowadzenie do tematu, a $w$ Części 2 omówione sa teoretyczne zagadnienia niezbędne do zrozumienia tematu, takie jak definicja eponimu czy socjolektu jako języka społeczności tanecznej. Część 3 wprowadza część praktyczna artykulu, zawierajac korpus 56 polskich eponimów $w$ terminologii tanecznej, zebranych głównie z książek takich jak "Słownik eponimów, czyli wyrazów odimiennych” (1996) $i$ „Stownik wyrazów obcych $i$ zwrotów obcojęzycznych” (2003) Władysława Kopalińskiego, ,Encyklopedia muzyki” (1995) Andrzeja Chodkowskiego czy „,W kręgu polskich tańców ludowych" (1979) Grażyny Dąbrowskiej, a także ustyszanych podczas różnych wykładów dotyczacych tańca, wraz z ich angielskimi odpowiednikami. Korpus poddany jest następnie analizie ilościowej i jakościowej. W Czesści 4 przedstawione sa konkluzje badań, 
wskazujace na złożoność zagadnienia eponimów oraz problemy, które moga wystapić w ich ttumaczeniu.

Słowa kluczowe: eponim, przekład, terminologia taneczna, socjolekt

\section{Introduction}

Different types of dance have been practiced since the beginning of time. From religious rituals to social gatherings, the role of dancing has mostly changed during the years and communities of dancers have emerged. Nowadays, there are communities of dancers of every style in every part of the world. Even though dancing is sometimes called a language itself, the language barrier in conveying the same movement may be visible, for instance, in the terminology of a given dance used in different countries.

To examine the vocabulary used in different countries for various dances practiced internationally, in the present paper, a part of dance terminology will be discussed, that is, the names of dance styles and moves which are eponyms in Polish, along with their English equivalents.

The purposes of this paper are threefold: to create a corpus of lexical units containing eponyms in dance terminology, to verify whether the terminology is similar in different languages, taking into account the fact that various dance styles are practiced internationally, and to determine which obstacles the translator may face while translating a text containing eponyms related to dance.

\section{Theoretical background}

\subsection{Definition of an eponym}

To begin with, it is necessary to define what an eponym is and what is the etymology of this term. Due to space limitations, only a few definitions will be presented; however, it has to be pointed out that many more definitions can be found in other resources.

The term "eponym" comes from the Greek word epônymos/epônumos, created with affixes epi and ónoma, meaning "something or somebody giving the name" (Sadowski 2013: 15). In ancient times, eponyms were officers (e.g. consuls) or people whose name served as a city or a tribe name (for instance gods or heroes) (Rudnicka 2004).

Thomas McArthur (1996: 350), in his The Oxford Companion to the English Language, presented an eponym as (a) "a personal name from which a word has been derived", (b) "the 
person whose name is so used", and (c) "the word so derived". Two of these definitions (a, c) are also presented in the Collins English Dictionary along with another one saying that an eponym is "any ancient official whose name was used to designate his year of office" ${ }^{1}$; however, in the present paper, the last definition will not be further discussed.

As stated, the scope of the term may differ depending on a person and circumstances. That is why Rudnicka (2004) suggests making a new term - "eponymism" for the word derived from an eponym. However, the suggested neologism does not seem to gain popularity, so, in this paper, the word "eponym" will be used to describe "a common word which has been singled out in a language on the principle of displacing one lexical item from the class of proper names to the class of common words with simultaneous attribution of metaphorical lexical meaning and - usually, but not in every language - the change of writing" (Rudnicka 2004), which is one of the most detailed and precise definitions.

\subsection{Dance terminology as an example of a social dialect: definition of a sociolect}

The spectrum of lexical items to be analysed in this paper is a part of a specific language, which is the language of dancers. As a result, it is useful to concentrate on that language variety for a moment.

Language used by a community, for instance the community of dancers, can be described as a 'sociolect' or a 'social dialect' (Trudgill 2003). Trudgill defines sociolect as "a variety or lect which is thought of as being related to its speakers' social background rather geographical background" (Trudgill 2003: 122). Social language varieties may be developed on the basis of different factors, such as gender, age, and ethnicity, among others; however, these factors are not the most important, as "people are influenced linguistically (...) much more by close friends, family members, work-mates, and members of other social networks to which they belong" (Chambers and Trudgill 1998: 64). Therefore, members of a social group should maintain strong bonds by frequent contact with each other for a sociolect to exist (Wilkoń 2000: 92).

What is more, a type of a sociolect "which unites people of similar professions or any kind of activity" (Khokhlova 2017: 16) is called a professional dialect or a professiolect. Grabias (2001) distinguishes its three characteristic traits: (1) high level of professionality, i.e. the existence of professional terminology, (2) low level of expressiveness, and (3) low level of secrecy. Therefore, the purpose of a professiolect is to facilitate the communication at work, describe specific objects or phenomena and talk about them, not to express opinions nor to code

\footnotetext{
${ }^{1}$ Source: http://www.dictionary.com/browse/eponym. Date: 28.08.2020.
} 
or hide any messages from other groups in society. Nevertheless, because its terminology is specific to a given field, this language variety can be incomprehensible for other people (Murrmann 2014).

It is presumed that dancers form a strong, international community because of the fact that they meet during various dancing festivals and competitions in their countries as well as abroad. Therefore, it is likely that their sociolect is not restricted to national frontiers. Chambers and Trudgill (1998: 166) state that "innovations leap from one place (...) to another (...), and then move into the places between". For instance, ballet terminology can be discussed in terms of spatial diffusion, as France is where ballet developed and where most terms and steps were created, and, until today, this original, unchanged French terminology is still used by dancers, dance teachers, and choreographers, no matter their nationality.

Furthermore, because dancing is a physical activity trained through practice, taught in majority orally, the language of dancers is mainly spoken. Of course, there are numerous books about dance and many written manuals, but mostly for ballet, ballroom dance (e.g. waltz, tango, foxtrot) or national dances (e.g. Polish polonez). There are not many or even none officially written resources on other social or newer dances, usually those which were traditionally danced by ordinary people, not necessarily meant for the stage (e.g., oriental dance has no written manuals containing officially approved terms or steps, as it originates from the dances of the ordinary people of Egypt and has been continuously evolving). The knowledge is therefore transmitted from teacher to teacher and then to the students.

Dancers' sociolect can be divided into two: (a) occupational variety, professiolect, dominated by referential function, used to describe the official terms, and (b) slang, primarily expressive, used to convey feelings (Grabias 1997: 145-159). The vocabulary discussed later in this paper belongs to the first type, as it is easier to find its reliable sources.

\section{The corpus of 56 Polish eponyms with their English translations and its quantitative and qualitative analysis}

The analysis will present 56 selected eponyms in the Polish language and their English translations. Polish material comes mostly from Kopaliński’s “Słownik eponimów, czyli wyrazów odimiennych" (1996) and his "Słownik wyrazów obcych i zwrotów obcojęzycznych" (2003), Chodkowski’s “Encyklopedia muzyki” (1995), Dąbrowska’s “W kręgu polskich tańców ludowych" (1979), while 11 lexical items were collected during various dance lectures and 
4 were found on dance schools' websites and in online articles. Then, some English translations were found using publications on dance, such as Craine and Mackrell's "The Oxford Dictionary of Dance" (2010), Haigh's “The Fiddle Handbook" (2009) and Newman's “Dances of to-day" (1914), while other English equivalents were found on blogs and websites belonging to dance schools, dance teachers or dance researchers, as well as in online articles. Full list of references for all lexical units and their translations is available at the end of this article.

\subsection{Division of eponyms}

The collected material is big enough to be divided into five categories, which depend on the type of the proper noun that is the source of a derived eponym (see e.g. Table 1).

\subsubsection{Eponyms derived from proper names of countries and regions}

This subsection presents a quantitative analysis of the selected eponyms in a pair of languages - Polish and English, in which the proper name, which is the basis for an eponym, signifies a country or a region.

Table 1. Eponyms derived from proper names of countries and regions (source: author).

\begin{tabular}{|c|c|c|}
\hline Polish eponym & English eponym/equivalent & Meaning \\
\hline anglez & anglaise & $\begin{array}{c}\text { a group of social dances of } \\
\text { the British Isles (French: } \\
\text { "English') }\end{array}$ \\
\hline arabeska, arabesque & arabesque & $\begin{array}{c}\text { a position in ballet (French: } \\
\text { "in Arabic fashion") and in } \\
\text { oriental dance }\end{array}$ \\
\hline conga & Conga/Conga Line & $\begin{array}{c}\text { Cuban carnival dance (from } \\
\text { the African region of Congo) }\end{array}$ \\
\hline écossaise & $\begin{array}{c}\text { a type of contradance (a) } \\
\text { dance danced in pairs in } \\
\text { which the pairs form a line } \\
\text { and face each other) in } \\
\text { a Scottish style (French: } \\
\text { "Scottish") }\end{array}$ \\
\hline halling & halling & $\begin{array}{c}\text { a Norwegian folk dance } \\
\text { (from the valley of } \\
\text { Hallingdal near Oslo) }\end{array}$ \\
\hline ländler & ländler & $\begin{array}{c}\text { Austrian folk dance } \\
\text { (German: Landl - region in } \\
\text { upper Austria where the } \\
\text { dance comes from) }\end{array}$ \\
\hline & polonaise & $\begin{array}{c}\text { a dance of Polish origin in } 3 / 4 \\
\text { time (French: Polish) }\end{array}$ \\
\hline
\end{tabular}




\begin{tabular}{|c|c|c|}
\hline siwa & siwa & $\begin{array}{c}\text { a folkloric Arabic dance } \\
\text { (from the Siwa Oasis) }\end{array}$ \\
\hline sri lanca & sri lanca & $\begin{array}{c}\text { a step in dancehall (in } \\
\text { memory of people who } \\
\text { fought in wars in Sri Lanca) }\end{array}$ \\
\hline sztajer & Rosentaler Steirischer & $\begin{array}{c}\text { an Austrian folkloric dance } \\
\text { (from the Austrian state }- \\
\text { Styria, German: Steiermark) }\end{array}$ \\
\hline
\end{tabular}

As a result, there are ten eponyms in the group (Table 1), all of which have eponymous English translation. As many as seven lexemes are internationalisms, as their spelling does not change in either language (except for Conga, which begins with a capital letter in English, and écossaise, which lacks accent in its English equivalent). Two lexemes are phonetically similar: anglez and polonez are borrowed from the original French terms anglaise and polonaise with Polish spelling. What is more, the term Steirischer can be phonetically associated with the Polish sztajer. Then, there are two cases of double equivalents. Firstly, in Polish, there are two terms arabeska and arabesque for English arabesque. The first term is used by Polish oriental dance teachers for a move similar to arabesque, used by ballet teachers. What is interesting, Englishspeaking teachers do not differentiate the name of the oriental dance move from the name of the ballet move. Secondly, Polish conga has two equivalents in English: Conga and Conga line. It seems that these terms are used interchangeably, with Conga line used to stress that it is a line dance.

\subsubsection{Eponyms derived from proper names of cities}

In this subsection, the analysis of eponyms derived from proper names of cities and towns is presented.

Table 2. Eponyms derived from proper names of cities (source: author).

\begin{tabular}{|c|c|c|}
\hline Polish eponym & English eponym/equivalent & Meaning \\
\hline bergamasca & bergamasca & $\begin{array}{c}\text { clumsy rustic dance of Italian } \\
\text { origin (from the town of } \\
\text { Bergamo in Northern Italy) }\end{array}$ \\
\hline boston & $\begin{array}{c}\text { a ballroom dance of } \\
\text { Bmican origin (from the } \\
\text { city of Boston) }\end{array}$ \\
\hline charleston & charleston & $\begin{array}{c}\text { a ballroom dance of } \\
\text { American origin, danced to } \\
\text { jazz music (from the harbor } \\
\text { city of Charleston) }\end{array}$ \\
\hline
\end{tabular}




\begin{tabular}{|c|c|c|}
\hline madison & Madison & $\begin{array}{c}\text { an American novelty dance } \\
\text { (from the city of Madison } \\
\text { - the capital of Wisconsin } \\
\text { state) }\end{array}$ \\
\hline lambeth walk & Lambeth Walk & $\begin{array}{c}\text { walking dance (from the title } \\
\text { of Douglas Furber's } \\
\text { song, Lambeth-London's } \\
\text { district) }\end{array}$ \\
\hline kołomyjka & kolomyjka & $\begin{array}{l}\text { an Ukrainian folk dance } \\
\text { (from the eastern Galician } \\
\text { town of Kolomyia) }\end{array}$ \\
\hline kamarinskaja & Kamarinskaya & $\begin{array}{c}\text { quick Russian dance (from } \\
\text { the name of a little town in } \\
\text { Russia) }\end{array}$ \\
\hline gangnam style & Gangnam Style & $\begin{array}{l}\text { dance moves presented in the } \\
\text { "Gangnam Style" music } \\
\text { video (from the name of the } \\
\text { wealthy district in Seul) }\end{array}$ \\
\hline habanera & habanera & $\begin{array}{l}\text { Cuban dance (from the } \\
\text { capital city - Havana) }\end{array}$ \\
\hline padwana/pawana & pavane & $\begin{array}{l}\text { a slow } \\
\text { processional dance common } \\
\text { in Europe during the 16th } \\
\text { century (from the Italian } \\
\text { name of the city Padua - } \\
\text { Padova) }\end{array}$ \\
\hline tarantella & tarantella & $\begin{array}{l}\text { a group of various Italian } \\
\text { folk dances (from the name } \\
\text { of a Southern Italian } \\
\text { city Taranto) }\end{array}$ \\
\hline Virginia reel & Virginia reel & $\begin{array}{l}\text { a folk dance that dates from } \\
\text { the } 17 \text { th century (from the } \\
\text { name of the state of Virginia) }\end{array}$ \\
\hline
\end{tabular}

In Table 2, there are twelve eponyms, all of which have eponymous translation in English. Nine of these lexemes are spelled the same way in both languages (with the exceptions of the beginning with capital letters, as in Gangnam Style, Boston, Madison, and Lambeth Walk). It should be noted that the English term Boston is spelled with a capital letter while charleston is spelled with a minuscule, even though they are both ballroom dances ${ }^{2}$. Then, the rest of the units

${ }^{2}$ It may be explained by the fact that the sources of these two terms can be found in two different books published decades apart from each other (Boston can be found in the Newman's 1914 "Dances of to-day" and charleston in Craine and Mackrell's 2010 "The Oxford Dictionary of Dance"). Nevertheless, on Internet blogs, spelling of these terms with both the majuscule and the minuscule can be found (e.g. https://secretsofsolo.com/2020/08/the-history-of-the-charleston-dance/ for Charleston). 
have a similar form in both languages (with small differences such as the lack of the Polish letter " $\mathrm{\prime}$ " in the English equivalent of kołomyjka).

\subsubsection{Eponyms derived from proper names of members of ethnic groups and residents of particular regions}

Table 3. presents Polish eponyms in which the basis signifies the members of ethnic groups and residents of particular regions, along with their English equivalents.

Table 3. Eponyms derived from the names of members of ethnic groups and residents of particular regions (source: author).

\begin{tabular}{|c|c|c|}
\hline Polish eponym & English eponym/equivalent & Meaning \\
\hline allemande & allemande & $\begin{array}{c}\text { a renaissance and baroque } \\
\text { dance (French: "German"; } \\
\text { Alemanni, i.e. Germanic } \\
\text { tribes) }\end{array}$ \\
\hline mazur/mazurek & mazurka & $\begin{array}{c}\text { Polish folk dance (from the } \\
\text { name of a citizen of the } \\
\text { Mazovia region) }\end{array}$ \\
\hline lezginka & kujawiak & $\begin{array}{c}\text { national dance of the Lezgins } \\
\text { (people of the Caucasus } \\
\text { region) }\end{array}$ \\
\hline kujawiak & $\begin{array}{c}\text { a Polish folk dance (from the } \\
\text { region of Kujawy) }\end{array}$ \\
\hline krakowiak & krakowachok & $\begin{array}{c}\text { a fast Polish dance (from the } \\
\text { citizen of the city of Cracow) } \\
\text { an Ukrainian folk dance (term } \\
\text { can be translated } \\
\text { as "Little Cossack') }\end{array}$ \\
\hline gawot & gavotte & $\begin{array}{c}\text { a French dance (from the } \\
\text { Gavot, people of the Pays de } \\
\text { Gap region of Dauphiné } \\
\text { in France) }\end{array}$ \\
\hline
\end{tabular}

According to the data presented in Table 3, there are seven eponyms and each has its eponymous translation. Four have the same spelling (with the exception of the capital letter in Lezginka), one of which has two English equivalents (krakowiak borrowed from Polish and cracovienne borrowed from French). Then, two units are similar in both languages and one is pronounced in

3 The term mazur can be also found in English terminology, [e.g. https://polishmusic.usc.edu/research/dances/mazur/. Date: 28.08.2020]. 
the same way ${ }^{4}$ but its spelling differs (gawot is a Polish spelling of the originally French word gavotte).

\subsubsection{Eponyms derived from proper names of people and places}

This subsection discusses eponyms in which the proper name, which is the basis for an eponym, signifies particular people or places.

Table 4. Eponyms derived from proper names of people and places (source: author).

\begin{tabular}{|c|c|c|}
\hline Polish eponym & English eponym/equivalent & Meaning \\
\hline Big Apple & Big Apple & $\begin{array}{l}\text { American dance that } \\
\text { originated in the } 1930 \text { s (from } \\
\text { the name of a club in } \\
\text { Columbia) }\end{array}$ \\
\hline Gay Gordons & Gay Gordons & $\begin{array}{l}\text { Scottish social dance (from } \\
\text { the name of a Scottish } \\
\text { regiment, the Gordon } \\
\text { Highlanders) }\end{array}$ \\
\hline roger rabbit & roger rabbit & $\begin{array}{c}\text { a step in dancehall (from the } \\
\text { name of the main character } \\
\text { of the } 1988 \text { film Who } \\
\text { Framed Roger Rabbit) }\end{array}$ \\
\hline soheir zaki & Soheir Zaki & $\begin{array}{c}\text { a step in oriental dance (from } \\
\text { the name of a famous } \\
\text { oriental dancer) }\end{array}$ \\
\hline usain bolt & usain bolt & $\begin{array}{l}\text { a step in dancehall (from } \\
\text { the name of the famous } \\
\text { Jamaican Olympic sprinter) }\end{array}$ \\
\hline veronica campbell & veronica campbell & $\begin{array}{l}\text { a step in dancehall (from the } \\
\text { name of the Jamaican female } \\
\text { sprinter) }\end{array}$ \\
\hline zorba (sirtaki) & Zorbá's dance & $\begin{array}{c}\text { a popular } \\
\text { dance of Greek origin } \\
\text { (from the name of the main } \\
\text { character of the } 1964 \\
\text { film Zorba the Greek) }\end{array}$ \\
\hline
\end{tabular}

Table 4. presents seven eponyms and their eponymous translation. Six of the analysed units are the same in both languages, while the English equivalent of zorba, Zorbá 's dance, is created by the use of the word "dance" and the addition of the Saxon genitive to the name of the main character of the 1964 film Zorba the Greek.

\footnotetext{
${ }^{4}$ More specifically, the phonemes are the same, but the accent differs, as the accent of this term is put on the first syllable in Polish and on the last in English.
} 


\subsubsection{Eponymous adjectives}

Table 5. contains dance names in which an eponym is an epithet. This group is different from the others mentioned above, but it was necessary to distinguish it to elaborate on adjectives as eponyms. Eponyms in this group are created differently from most examples presented in subsections 3.1.1, 3.1.2., 3.1.3, and 3.1.4. in which eponyms were nouns. In this subsection, it is the adjective that is the eponym, and it is used together with a common noun signifying a dance in general, a dance type, or a step.

The choice of these eponyms being presented as a separate group is also explained by the fact that these eponymous adjectives can be often used independently, without the noun, both in English and in Polish (e.g. Jestem specjalista od cubany, I'm dancing Nubian tonight).

Table 5. Eponymous adjectives (source: author).

\begin{tabular}{|c|c|c|}
\hline Polish eponym & English eponym/equivalent & Meaning \\
\hline angielski walc & English Waltz & $\begin{array}{c}\text { a ballroom dance of English } \\
\text { origin }\end{array}$ \\
\hline salsa cubana & Cuban salsa/salsa cubana & $\begin{array}{c}\text { a popular Cuban dance } \\
\text { popularized in the } 1970 \mathrm{~s} \\
\text { (from the name of the isle of } \\
\text { Cuba) }\end{array}$ \\
\hline arabski taniec & Arabic dance & $\begin{array}{l}\text { another name for oriental } \\
\text { dance, or belly dance, } \\
\text { a dance of Arabic origin }\end{array}$ \\
\hline argentyńskie tango & Argentine tango & $\begin{array}{l}\text { classical tango of } \\
\text { Argentinian origin }\end{array}$ \\
\hline cygański taniec (gitana) & Gypsy/Romani dance & $\begin{array}{l}\text { a dance characteristic of } \\
\text { Romani community }\end{array}$ \\
\hline egipski (arabski) krok & basic step & $\begin{array}{c}\text { basic step in raqs sharki } \\
\text { (from the Arabic region of } \\
\text { Egypt) }\end{array}$ \\
\hline nubijski taniec & Nubian dance & $\begin{array}{l}\text { a type of folkloric Arabic } \\
\text { dance which comes from } \\
\text { Nubia region (northern } \\
\text { Sudan and southern Egypt) }\end{array}$ \\
\hline powolniak kurpiowski & powolniak kurpiowski & $\begin{array}{l}\text { a fast dance }{ }^{5} \text { of Polish origin } \\
\text { (from the name "Kurpie" } \\
\text { signifying both the citizens } \\
\text { of northern Mazovia and the } \\
\text { name of this part of Mazovia } \\
\text { region) }\end{array}$ \\
\hline
\end{tabular}

${ }^{5}$ What is interesting, the word "powolniak" is derived from the Polish adjective "powolny", which means "slow". Therefore, the name of this dance does not represent its fast tempo. 


\begin{tabular}{|c|c|c|}
\hline wiedeński walc & Viennese Waltz & $\begin{array}{c}\text { a type of a ballroom dance } \\
\text { (from the name of Vienna - } \\
\text { the capital of Austria) }\end{array}$ \\
\hline
\end{tabular}

There are nine eponyms in this group. It is the only group in which one of the eponyms does not have its eponymous translation and that is "krok egipski/arabski" being translated as "basic step". It can be explained by the fact that this move is used in oriental dance, a dance with no official list of recognized steps and no official manual, so the terminology can vary not only from country to country, but also from teacher to teacher.

\subsection{Problems occurring in translation of eponyms}

Having presented the 56 lexical units and their translations, it is visible that there may occur certain problems in translation.

First of all, there are no clear rules about starting the word with a capital letter. Most of the Polish lexemes began with a small letter (only typical English loanwords like Big Apple started with a capital one), whereas it was not so evident in the case of their English equivalents. All units found in the "Oxford Dictionary of Dance" (Craine, Mackrell 2010) start with a minuscule; however, having analysed other reliable sources used to find English equivalents (e.g. Newman's "Dances of to-day" or websites such as ColumbusMusicHistory.com or McCallumTheatre.com), it cannot be stated that it is a rule.

Secondly, there were some problems in finding an equivalent for certain words. Dances like sztajer and powolniak kurpiowski were not present in English publications on dance, neither were they discussed on English websites very often, and if they were, the internet posts were usually written by Polish users. This leads to the question of whether the source of the equivalent can be trusted. Therefore, there is a need for further research and more data proving that these regional dances exist in English-speaking cultures and have a known English equivalent.

Lastly, in 5 out of 56 cases, one Polish word had more than one English equivalent. For instance, krakowiak can be translated into English as krakowiak or cracovienne. In that case, the question that a translator must ask is which form would be the best one. It is the translator's responsibility, if they are not an expert in the field of dance, to consult all possible sources to choose the best form. As there seems to be no data confirming which options are used more frequently, one possible solution would be to consult a dancer from the target culture.

All the above-mentioned problems that can occur in translation are the consequences of and can be explained by the fact that the dancers' social dialect is mainly oral. As previously stated 
in Section 2.2., depending on a dance style, there are usually not many publications on the topic since all the information about dance origins, movements, and technique is generally shared orally during workshops and lectures.

\subsection{Eponyms in dance terminology as an example of linguistic interculturality}

As many as 30 out of the 56 eponyms (54\%) had the same form in the analysed pair of languages. In majority, other units had similarities in both languages too. This fact serves a communicational purpose, as, thanks to the use of the same terminology, dancers can communicate no matter from where they are. For example, if a Polish ballet dancer attends an advanced ballet course in the United States and learns from an American choreographer, they understand what to do thanks to the fact that the names of steps are the same in every language.

Furthermore, the analysed terminology originally comes from many different languages (e.g. anglez/anglais from French, kujawiak from Polish, salsa from Spanish), so it can be stated that the origins of the dances are visible and respected in the analysed languages.

Therefore, there are reasons to claim that the professiolect of dancers is intercultural. According to Popescu and Sorcaru (2008: 18), interculturality is "the creation, change, conversion and transfer of knowledge, basically performed by a wide variety of signs, words included". This definition seems to perfectly describe dance communities, in which we can observe all of the above. Moreover, this paper proves that dance is international not only in the non-verbal "variety of signs" such as steps and choreographies performed by dancers but also in terms of their verbal communication, i.e. terminology.

\section{Conclusion}

Taking into consideration both the abovementioned theoretical analysis and the quantitative and qualitative analysis of Polish eponyms and their English equivalents, it can be stated that there are various problems that a translator has to face during the translation process of eponyms. Dance terminology is a specific field of lexical items which are mainly spoken. This results in the lack of (or a low number of) written resources on which a translator could rely.

Then, dance terminology has been discussed as an example of linguistic interculturality, with the majority of terms being the same or similar in both languages. Dancers' professiolect therefore not only does conform with Grabias's (2001) characteristics of a professiolect presented in Subsection 2.2., serving communication purposes, but also with Chambers and 
Trudgill's (1998: 168) claim that a dialect does not necessarily need to have a relation with particular language frontiers.

Summing up, it appears that dance terminology is a matter of difficult decisions for a translator. To add to the research on the language of dancers, a study on dancers' slang could be conducted in the future. Moreover, there is still a lot to be done in the field of linguistics and translation studies to verify whether other types of eponyms can be a problem in translation, too, since the topic of eponymy and translation is not widely discussed in linguistic research.

Appendix: alphabetical chart of discussed eponyms (source: author).

\begin{tabular}{|c|c|c|}
\hline Polish eponym & English eponym/equivalent & Meaning \\
\hline allemande & allemande & $\begin{array}{c}\text { a renaissance and baroque dance (French: } \\
\text { "German"; Alemanni, i.e. Germanic } \\
\text { tribes) }\end{array}$ \\
\hline angielski walc & English Waltz & A ballroom dance of English origin \\
\hline anglez & anglaise & $\begin{array}{l}\text { a group of social dances of the British Isles } \\
\text { (French: "English") }\end{array}$ \\
\hline $\begin{array}{l}\text { arabeska, } \\
\text { arabesque }\end{array}$ & arabesque & $\begin{array}{l}\text { a position in ballet (French: "in Arabic } \\
\text { fashion") and in oriental dance }\end{array}$ \\
\hline arabski taniec & Arabic dance & $\begin{array}{l}\text { another name for oriental dance, or belly } \\
\text { dance, a dance of Arabic origin }\end{array}$ \\
\hline argentyńskie tango & Argentine tango & classical tango of Argentinian origin \\
\hline bergamasca & bergamasca & $\begin{array}{l}\text { clumsy rustic dance of Italian origin (from } \\
\text { the town of Bergamo in Northern Italy) }\end{array}$ \\
\hline Big Apple & Big Apple & $\begin{array}{l}\text { American dance that originated in the } \\
\text { 1930s (from the name of a club } \\
\text { in Columbia) }\end{array}$ \\
\hline boston & Boston & $\begin{array}{l}\text { a ballroom dance of American origin (from } \\
\text { the city of Boston) }\end{array}$ \\
\hline charleston & charleston & $\begin{array}{c}\text { a ballroom dance of American origin, } \\
\text { danced to jazz music (from the harbor city } \\
\text { of Charleston) }\end{array}$ \\
\hline conga & Conga/Conga Line & $\begin{array}{l}\text { Cuban carnival dance (from the African } \\
\text { region of Congo) }\end{array}$ \\
\hline $\begin{array}{l}\text { cygański taniec } \\
\text { (gitana) }\end{array}$ & Gypsy/Romani dance & $\begin{array}{l}\text { a dance characteristic to Romani } \\
\text { community }\end{array}$ \\
\hline écossaise & ecossaise & $\begin{array}{l}\text { a type of contradance (a dance danced in } \\
\text { pairs in which the pairs form a line and } \\
\text { face each other) in a Scottish style (French: } \\
\text { "Scottish") }\end{array}$ \\
\hline $\begin{array}{l}\text { egipski (arabski) } \\
\text { krok }\end{array}$ & basic step & $\begin{array}{l}\text { basic step in raqs sharki (from the Arabic } \\
\text { region of Egypt) }\end{array}$ \\
\hline gangnam style & Gangnam Style & $\begin{array}{l}\text { dance moves presented in the "Gangnam } \\
\text { Style" music video (from the name of the } \\
\text { wealthy district in Seul) }\end{array}$ \\
\hline
\end{tabular}




\begin{tabular}{|c|c|c|}
\hline gawot & gavotte & $\begin{array}{l}\text { a French dance (from the Gavot, people } \\
\text { of the Pays de Gap region of Dauphiné } \\
\text { in France) }\end{array}$ \\
\hline Gay Gordons & Gay Gordons & $\begin{array}{c}\text { Scottish social dance (from the name } \\
\text { of a Scottish regiment, the Gordon } \\
\text { Highlanders) }\end{array}$ \\
\hline habanera & habanera & $\begin{array}{l}\text { Cuban dance (from the capital } \\
\text { city - Havana) }\end{array}$ \\
\hline halling & halling & $\begin{array}{c}\text { a Norwegian folk dance (from the valley of } \\
\text { Hallingdal near Oslo) }\end{array}$ \\
\hline kamarinskaja & Kamarinskaya & $\begin{array}{l}\text { quick Russian dance (from the name } \\
\text { of a little town in Russia) }\end{array}$ \\
\hline kołomyjka & kolomyjka & $\begin{array}{l}\text { an Ukrainian folk dance (from the eastern } \\
\text { Galician town of Kolomyia) }\end{array}$ \\
\hline kozak & kozachok & $\begin{array}{l}\text { an Ukrainian folk dance (term can be } \\
\text { translated as "Little Cossack") }\end{array}$ \\
\hline krakowiak & krakowiak/cracovienne & $\begin{array}{l}\text { a fast Polish dance (from the citizen } \\
\text { of the city of Cracow) }\end{array}$ \\
\hline kujawiak & kujawiak & $\begin{array}{l}\text { a Polish folk dance (from the region } \\
\text { of Kujawy) }\end{array}$ \\
\hline lambeth walk & Lambeth Walk & $\begin{array}{l}\text { walking dance (from the title of Douglas } \\
\text { Furber's song, Lambeth-London's district) }\end{array}$ \\
\hline ländler & ländler & $\begin{array}{l}\text { Austrian folk dance (German: Landl- } \\
\text { region in upper Austria where the dance } \\
\text { comes from) }\end{array}$ \\
\hline lezginka & Lezginka & $\begin{array}{c}\text { national dance of the Lezgins (people } \\
\text { of the Caucasus region) }\end{array}$ \\
\hline madison & Madison & $\begin{array}{l}\text { an American novelty dance (from the city } \\
\text { of Madison - the capital of Wisconsin } \\
\text { state) }\end{array}$ \\
\hline mazur/mazurek & mazurka & $\begin{array}{l}\text { Polish folk dance (from the name } \\
\text { of a citizen of the Mazovia region) }\end{array}$ \\
\hline nubijski taniec & Nubian dance & $\begin{array}{c}\text { a type of folkloric Arabic dance which } \\
\text { comes from Nubia region (northern Sudan } \\
\text { and southern Egypt) }\end{array}$ \\
\hline padwana/pawana & pavane & $\begin{array}{l}\text { a slow processional dance common in } \\
\text { Europe during the 16th century (from the } \\
\text { Italian name of the city Padua - Padova) }\end{array}$ \\
\hline $\begin{array}{l}\text { powolniak } \\
\text { kurpiowski }\end{array}$ & powolniak kurpiowski & $\begin{array}{l}\text { a fast dance of Polish origin (from the } \\
\text { name of the citizens of northern Mazovia } \\
\text { or from the name of the whole region) }\end{array}$ \\
\hline polonez & polonaise & $\begin{array}{l}\text { a dance of Polish origin in } 3 / 4 \text { time (French: } \\
\text { Polish) }\end{array}$ \\
\hline roger rabbit & roger rabbit & $\begin{array}{c}\text { a step in dancehall (from the name } \\
\text { of the main character of the } 1988 \text { film Who } \\
\text { Framed Roger Rabbit) }\end{array}$ \\
\hline salsa cubana & Cuban salsa/salsa cubana & $\begin{array}{l}\text { a popular Cuban dance popularized in the } \\
1970 \text { s (from the name of the isle of Cuba) }\end{array}$ \\
\hline
\end{tabular}




\begin{tabular}{|c|c|c|}
\hline siciliana & siciliana/siciliano/sicilienne & $\begin{array}{l}\text { a musical style often included as } \\
\text { a movement, from the Baroque period } \\
\text { (from the name of Italian isle Sicily) }\end{array}$ \\
\hline siwa & siwa & $\begin{array}{l}\text { a folkloric Arabic dance (from the Siwa } \\
\text { Oasis) }\end{array}$ \\
\hline sri lanca & sri lanca & $\begin{array}{l}\text { a step in dancehall (in memory of people } \\
\text { who fought in wars in Sri Lanca) }\end{array}$ \\
\hline soheir zaki & Soheir Zaki & $\begin{array}{l}\text { a step in oriental dance (from the name } \\
\text { of a famous oriental dancer) }\end{array}$ \\
\hline sztajer & Rosentaler Steirischer & $\begin{array}{c}\text { an Austrian folkloric dance (from the } \\
\text { Austrian state - Styria, German: } \\
\text { Steiermark) }\end{array}$ \\
\hline tarantella & tarantella & $\begin{array}{c}\text { a group of various Italian folk dances } \\
\text { (from the name of a Southern Italian } \\
\text { city Taranto) }\end{array}$ \\
\hline usain bolt & usain bolt & $\begin{array}{l}\text { a step in dancehall (from the name } \\
\text { of the famous Jamaican Olympic sprinter) }\end{array}$ \\
\hline veronica campbell & veronica campbell & $\begin{array}{l}\text { a step in dancehall (from the name } \\
\text { of the Jamaican female sprinter) }\end{array}$ \\
\hline Virginia reel & Virginia reel & $\begin{array}{l}\text { a folk dance that dates from the } 17 \text { th } \\
\text { century (from the name of the state } \\
\text { of Virginia) }\end{array}$ \\
\hline wiedeński walc & Viennese Waltz & $\begin{array}{l}\text { a type of a ballroom dance (from the name } \\
\text { of Vienna - the capital of Austria) }\end{array}$ \\
\hline zorba (sirtaki) & Zorbá's dance & $\begin{array}{l}\text { a popular dance of Greek origin (from the } \\
\text { name of the main character of the } 1964 \\
\text { film Zorba the Greek) }\end{array}$ \\
\hline
\end{tabular}

\section{Sources of eponyms and their translations}

Sources of Polish eponyms

- Kopaliński’s “Słownik eponimów, czyli wyrazów odimiennych” (1996): bergamasca, boston, charleston, écossaise, gawot, habanera, lezginka, mazur/mazurek, padwana/pawana, siciliana, sztajer, tarantella.

- Kopaliński’s "Słownik wyrazów obcych i zwrotów obcojęzycznych" (2003): allemande, anglez, Big Apple, conga, cygański taniec (gitana), halling, kamarinskaja, lambeth walk, ländler, madison, Virginia reel.

- Chodkowski’s "Encyklopedia muzyki” (1995): angielski walc, argentyńskie tango, kołomyjka, kozak, krakowiak, kujawiak, polonez, wiedeński walc.

- Dąbrowska’s “W kręgu polskich tańców ludowych” (1979): powolniak kurpiowski 
- Oriental dance lectures: arabeska, arabesque, arabski taniec, egipski (arabski) krok, nubijski taniec, siwa, soheir zaki (teachers who use these terms are: Katarzyna Wronka, Małgorzata Gil-Manzel, Agnieszka Kubaczka among others).

- Dancehall lectures: roger rabbit, sri lanca, usain bolt, veronica campbell (teachers who use these terms are Daria Nędza-Stabrawa and Monika Tokarska among others).

- gangnam style, retrieved from: https://radomsko.naszemiasto.pl/gangnam-style-w-mdkczyli-zimowe-warsztaty-dla-mlodziezy/ar/c13-1693791. Date: 28.08.2020.

- Gay Gordons, retrieved from: https://www.circledance.pl/o-tancach/tance-szkockie/. Date: 28.08.2020.

- salsa cubana, retrieved from: https://www.novaszkolatanca.pl/katowice/taniec/salsacubana. Date: 28.08.2020.

- zorba (sirtaki), retrieved from: https://www.taniecpolska.pl/krytyka/699. Date: 28.08.2020.

Sources of English eponyms/equivalents:

- Craine and Mackrell's “The Oxford Dictionary of Dance” (2010), retrieved from: https://www.oxfordreference.com/view/10.1093/acref/9780199563449.001.0001/acref9780199563449: ecossaise, allemande, anglaise, arabesque, bergamasca, charleston, gavotte, habanera, krakowiak/cracovienne, ländler, mazurka, pavane, polonaise, tarantella

- Haigh's “The Fiddle Handbook” (2009): kolomyjka, kozachok, kujawiak, Gay Gordons

- Newman's “Dances of to-day" (1914): Argentine tango, Boston

- English Waltz: https://dancehistory.trueillusion.bg/s_eng_waltz_en.html

- Big Apple: http://www.lindycircle.com/history/big apple/

- Conga/Conga Line: http://www.streetswing.com/histmain/z3conga.htm

- Gypsy/Romani dance: http://www.gypsydance.org/what-is-gypsy-dance/

- basic step - term used during oriental dance lectures and workshops by various teachers, Julia Torgonska and Mercedes Nieto among others.

- Gangnam Style: https://www.businessinsider.com/gangnam-style-dance-tutorial-20137\#some-moves-though-just-cant-be-taught-8

- halling: https://adopt-a-countrynorway.weebly.com/the-halling-dance.html

- Kamarinskaya: https://www.rusclothing.com/blog/kamarinskaya-dance/

- Lambeth Walk: https://www.marshandparsons.co.uk/blog/the-history-of-the-lambethwalk/ 
- Lezginka: https://www.mccallumtheatre.com/download.php/education/fieldtrips/downloads/lezginka-state-dance

- Madison: http://www.columbusmusichistory.com/html/madison_1.html

- Nubian dance: http://www.mohamedshahin.net/egy_dan.html

- powolniak kurpiowski:

http://www.folkdancecamp.org/assets/Powolniak Kurpiowska Puszcza Zielona2012S FDC.pdf

- roger rabbit, sri lanca, usain bolt, veronica campbell: http://www.danceja.com/dancemoves

- Cuban salsa/salsa cubana: https://razbakov.com/dancing/salsa-cubana/

- siciliana/siciliano/sicilienne: https://www.oxfordmusiconline.com/grovemusic/view/10.1093/gmo/9781561592630.0 $\underline{01.0001 / o m o-9781561592630-e-0000025698}$

- $\quad$ siwa: http://old.sameh-pharaounic.com/engl/his.htm

- Soheir Zaki: http://www.helenbellydance.com/is-this-the-most-iconic-bellydancemove-of-all-time-how-to-dance-like-soheir-zaki/

- Rosentale Steirischer: http://folkdancemusings.blogspot.com.es/2014/08/rosentaler$\underline{\text { steirischer-austria.html? } \mathrm{m}=1}$

- Virginia reel: http://users.rowan.edu/ conet/rhythms/CulturalDances/VirginiaReel.html

- Viennese Waltz: https://dancehistory.trueillusion.bg/s_vienne_waltz_en.html

- Zorbá's dance: https://neoskosmos.com/en/156713/there-are-many-benefits-when-itcomes-to-greek-dancing/

All online sources retrieved on 28 August 2020.

\section{References}

Chambers, Jack, Peter Trudgill (1998) Dialectology. New York: Cambridge University Press. Chodkowski, Andrzej (1995) Encyklopedia muzyki. Warszawa: Wydawnictwo PWN.

Collins English Dictionary - Complete \& Unabridged. Edition 2009: “Eponym”. Retrieved from: http://dictionary.reference.com/browse/eponym. Date: 28.08.2020.

Craine, Debra, Judith Mackrell (2010) The Oxford Dictionary of Dance. Oxford: Oxford University Press.

Dąbrowska, Grażyna (1979) W kręgu polskich tańców ludowych. Warszawa: Ludowa 
Spółdzielnia Wydawnicza.

Grabias, Stanisław (1997) Język w zachowaniach społecznych. Lublin: Wydawnictwo

Uniwersytetu Marii Curie Skłodowskiej.

Grabias, Stanisław (2001) “Środowiskowe i zawodowe odmiany języka - socjolekty”. [In:]

Jerzy Bartmiński. (ed.) Współczesny język polski; 223-240. Lublin: UMCS.

Haigh, Chris (2009) The Fiddle Handbook. London: Backbeat Books.

Khokhlova, Irina Nickolaevna (2017) “Contact Variantology: Problems of National Language

Variety Terminology”. Saudi Journal of Humanities and Social Sciences 2017; 2 (1); 15-

18. Retrieved from: http://scholarsmepub.com/wp-content/uploads/2017/02/SJHSS-2115-

18.pdf. Date: 28.08.2020.

Kopaliński, Władysław (2003) Słownik wyrazów obcych $i$ zwrotów obcojęzycznych z almanachem. Warszawa: Wydawnictwo PWN.

Kopaliński, Władysław (1996) Słownik eponimów, czyli wyrazów odimiennych. Warszawa: Wydawnictwo PWN.

Lewandowski, Marcin (2008) “The Language of Soccer - a Sociolect or a Register?” [In:] P.

Nowak, P. Nowakowski (eds.) Język, Komunikacja, Informacja, 3/2008: 21-32.

Retrieved from: https://repozytorium.amu.edu.pl/bitstream/10593/4562/1/02-

Lewandowski.pdf. Date: 28.08.2020.

McArthur, Thomas (1996) The Oxford Companion to the English Language. Oxford: Oxford University Press.

Murrmann, Julia (2014) Profesjolekt branży turystycznej, czyli o specyficznych cechach zawodowego języka turystyki” [In:] Rozprawy Naukowe Akademii Wychowania Fizycznego we Wrocławiu 47; 47-57. Retrieved from:

http://cejsh.icm.edu.pl/cejsh/element/bwmeta1.element.desklight-b05414f5-c42f-49b0b7b0-810e26136e00. Date: 28.08.2020.

Newman, Albert (1914) Dances of to-day, Philadelphia: The Penn Publishing Co.

Popescu, Floriana, Daniela Sorcaru (2008) Eponyms: An Instance of Linguistic

Interculturality. Retrieved from:

https://www.yumpu.com/en/document/view/9502218/culture-subculture-andcounterculture-facultatea-de-litere/167. Date: 28.08.2020.

Rudnicka, Ewa (2004) "Eponimical Lexical Items as the Object of Translation”. [In:] Вісник Сумского державного університету, серія “Філологічні науки” 4 (63); 154-161.

Retrieved from: http://www.vuzlib.com.ua/articles/book/25635-

Eponymical_lexical_items_as_th/1.html. Date: 28.08.2020. 
Sadowski, Mirosław (2013) „Eponimy jako sposób wzbogacania leksyki” [In:] Acta Erasmiana. Retrieved from:

https://www.academia.edu/15578944/Eponimy_jako_spos\%C3\%B3b_wzbogacania_leksy ki Eponyms as a mean of enriching vocabulary. Date: 28.08.2020.

Trudgill, Peter (2003) A Glossary of Sociolinguistics. Edinburgh: Edinburgh University Press.

Wilkoń, Aleksander (2000) Typologia odmian językowych współczesnej polszczyzny.

Katowice: Wydawnictwo Uniwersytetu Śląskiego. 